\title{
CULTURAL INFLUENCES ON FOREIGN DIRECT INVESTMENT
}

Marcelo Ribeiro Goraieb ${ }^{1}$, Maurício Reinert do Nascimento \& Fabiane Cortez Verdu Universidade Estadual de Maringá - UEM, Paraná, (Brazil)

\section{DETALHES DO ARTIGO}

\section{Article history}

Received: 03 May 2018

Accepted: 08 November 2018

Available online April: 01th 2019

Double Blind Review System

\section{Editor Científico}

Ilan Avrichir

\section{Keywords}

Cultural Influences

Foreign Direct Investment (FDI)

National Cultures

Cultural Distance

Hofstede

\section{RESUMO}

The current business competitive environment has influenced companies to cross national borders to explore foreign markets. The decision about in which country the company should invest isn't easy. Many factors can influence this decision, and culture is one of factors that international business scholars have incorporated in their researches. This article deals with the influence of cultural distances on Foreign Direct Investment, specifically it aims to examine whether cultural values affects bilateral Foreign Direct Investment, that is, Foreign Direct Investment Stock. Data that include bilateral Multiple Regression Quadratic Assignment Procedure technique between 45 countries in 2007 were used, representing almost 95\% of the Foreign Direct Investment Stock worldwide. The Multiple Regression Quadratic Assignment Procedure technique was used. It was found that the similarities in Power Distance between two countries positively affects the Foreign Direct Investment stock between them (it means that companies prefer countries similar from their home country) and the presence of high Uncertainty Avoidance in one or in both countries of a dyad negatively affects the Foreign Direct Investment stock between them (it means that companies avoid countries that are different from their home country). Contributions: (1) uses an innovative approach Multiple Regression Quadratic Assignment Procedure technique to analyze how individual cultural dimensions influence Foreign Direct Investment; (2) responds to the critique by Shenkar, by applying separate rather than aggregate cultural distance; (3) unveils how some cultural dimensions work in influencing FDI.

(C) 2018 Internext | ESPM. Todos os direitos reservados!

\section{INTRODUCTION}

The current business competitive environment has influenced companies to cross national borders to explore foreign markets and investing in them. The decision about in which country the company should invest isn't easy. Many factors can influence this decision, and culture is one of factors that international business scholars have incorporated in their researches.

Foreign Direct Investment (FDI) is a key element in understanding Globalization. Countries more susceptible to this kind of investment have higher chances of attaining economic development, so much so that being the recipient of FDI is one of the indicators in this type of analysis. Therefore, it is necessary to understand what will influence FDI to happen. Research on the subject has focused more on the economic, geographical and politicaladministrative aspects. More subjective factors, such as cultural ones, have been increasingly used when dealing with an influence of cultural values especially on two types of decision: (1) making a direct investment abroad (Du, Lu \& Tao, 2012; Feils \& Rahman, 2011; Makino \& Tsang, 2011; Malhotra, Sivakumar \& Zhu, 2009; Rothaermel, Kotha \& Steensma, 2006; Thomas \& Grosse, 2001), and (2) choosing a host country (Berry, Guillén \& Zhou, 2010; Dow \& Ferencikova, 2010; Delios \& Henisz, 2003a, 2003b). But these researches tend to investigate more objectives proxies of culture, such as language, or individual countries, analyzing how organizations 
in a country are influenced by more subjective aspects of culture in deciding where to invest. This paper addresses both at the same time. This is important because include in the models at the same time different countries together with objective and subjective measures of culture. It increases the robustness of the model and deepens the possible interpretations of the results because separate the cultural distance in the cultural dimensions proposed by Hofstede.

When discussing culture, we must discuss Hofstede work, which is the most cited book "Culture consequences" in the field (Beugelsdijk, Kostova \& Roth, 2017). Since the publication of this book (Hofstede, 1980), it has garnered attention of International Business (IB) researchers. Some of scholars address a key methodological challenge faced by research using it (Sivakumar \& Nakata, 2001; Kirkman, Lowe \& Gibson, 2006, 2017). One work of those, Kirkman et al. (2006) was chosen as Decade Award paper by Journal of International Business Studies. That means Hofstede's work still is important when the issue is culture.

Culture is an embracing concept as well as an important social element, since it arises from the interaction among people, who develop principles and values that are externalized through practices. In this research, the original work developed by Hofstede on cultural values in different countries was used, despite its limitations. It has defined four dimensions of cultural values that are present in all nations, because they represent answers to universal problems and that present slow change through time. These dimensions are (1) Power Distance; (2) Individualism or collectivism; (3) Masculinity or Femininity and (4) Uncertainty Avoidance.

This article deals with the influence of cultural distances on Foreign Direct Investment (FDI), specifically it aims to examine whether cultural values (power distance, individualism or collectivism, masculinity or femininity, uncertainty avoidance) affects bilateral FDI, that is, FDI Stock.

In International Business literature cultural distance construct is widely accepted, however its greatest impact is in FDI studies (Shenkar, 2001, 2012), which discuss (1) initial and subsequent FDI (Du et al., 2012), (2) modes and timing of entry (López-Duarte, Vidal-Suárez \& González-Diaz, 2015; Du et al., 2012), and (3) performance of subsidiaries.
The paper presents three main contributions. First, it contributes methodologically by using Social Network Analysis in studying decision in FDI. Assuming that FDI is an economic relationship and using network as a metaphor, this paper innovates in comparing similarities in culture and others measures to understand whether subjective dimensions of culture influences FDI using Multiple Regression Quadratic Assignment Procedure (MRQAP). This technique presents itself as appropriate for the dyads' analysis when the objective is to analyze the similarity in quantitatively measured behavior, in this case, similarity of cultural dimensions and its influence in FDI. Second, in disaggregating cultural distance in the dimensions proposed by Hofstede, it corroborates the hypothesis that culture distances have an impact in FDI stating that countries that have more similar Power Distance measures will have more FDI Stock in each other, even when controlling for similarities in Language usually used as proxy for culture. It means that even when two countries share the same language, a subjective characteristic of culture, such as Power Distance, influences de decision of investing abroad. Third, not only cultural distance is important, but cultural characteristics influence directly the decision of investment abroad. Host countries of FDI with High Uncertainty Avoidance received less FDI than Host Countries without High Uncertainty Avoidance. It seems that host countries were the cultural dimension uncertainty avoidance is high tend to make it more difficult to foreign countries to invest in it, even when they are cultural similar. This find reinforce the importance of understanding culture to better explain FDI decision.

\section{THEORETICAL BASIS}

In this item the concepts that support this research are presented: (1) influences in FDI, (2) economic, geographic and political-administrative factors, and (3) cultural factors.

\section{Influences in FDI}

Direct investment between countries was initially studied by economists (Andersson, 2004), for which "internationalization decisions are a consequence of rational analysis of, for example, transportation costs, tariffs and nontariff barriers, transaction costs, relative wages and market size (Andersson, 2004, p. 853).

For some authors as Ghemawat (2001) this exclusively economic analysis is not the best since it 
ignores the social risks involved in entering a new market. One of these social characteristics most prominent in FDI studies is the local culture (Bhardwaj, Dietz \&, Beamish, 2007).

Johanson and Valhne (1990, 2003, 2006, and 2009) and Schweizer, Valhne and Johanson (2010) suggest that the company cannot be individually analyzed, but as part of a network, that is, the way the connection to other companies is made must be understood. It is noticeable that the connection between the foreign headquarter and the target country's business network is important in order to allow the exchange of knowledge and activities to happen. Therefore, in the internationalization process, it is possible to analyze aspects beyond economics, aspects of a subjective nature, especially the culture of each nation.

In short, economic, geographic, politicaladministrative and cultural factors affect FDI (Ghemawat, 2001). GNP (Gross National Product) and per-capita GNP are taken into account in this work (economic factors); legal origin (politicaladministrative factors); border sharing and geographic distance (geographic factors); language and values such as cultural, that are social aspects and treated as determining factors in FDI between countries.

\section{Economic, Geographic and Political-Administrative Factors}

According to Ghemawat (2001) and from an economic point of view, wealth and consumer demand are the most important attributes for internationalization. Researches (Feenstra, Markusen \& Rose, 2001; Hejazi \& Ma, 2011) indicate that the higher the per-capita GNP, the higher the probability of economic activity occurring between the countries, thus developing the International Severity Economic Model that demonstrates a positive correlation between per-capita GNP and trade flow. This model also indicates that countries with a lower per-capita GNP present more activities with wealthy countries than other poorer countries.

The geographic distance in internationalization is not simply just, how far away one country is from the other, but also the size of the country, its sea access, its topography, its average distance from the interior to its borders and finally, transport infrastructure and communication made by man, must be taken into consideration. Thus, these factors influence the exchange of information and transportation costs (affecting intangible products such as service) (Ghemawat, 2001). The most significant geographic factor favoring FDI between countries is how close one country is from the other (Gao, 2005).

Shortening the political and administrative distance refers to, for example, to the connection between colony-colonizer when the relationship is amicable. Policies relating to trade, product and people entry and exit barriers, as well, may directly affect the relationship between countries. The existence of colonial ties between two countries does not favor one country to invest in the other, yet the existence of the same legal origin increases the investment flow between the countries in question (Hejazi \& Ma, 2011).

\section{Cultural Factors}

Even with the better integration between countries provided by globalization, cultural distance continues to exert important influence international business and to attract the attention of scholars (Leung, Bhagat, Erez \& Gibson, 2005; Tanure \& Duarte, 2006; Ghemawat, 2001; Goulart, Brasil \& Arruda, 1996). This occurs for the impact that Cultural Friction may cause business relationships, which may be indifferent, complementary or incompatible, and in this last case, hindering these relationships (Shenkar, 2012). Therefore, cultural differences are distances when they hinder a relationship, which can only be verified after contact between the cultures.

According to Polanyi (1944, p. 46): "man's economy, as a rule, is submerged in his social relationships". This research has been accomplished under this social embeddedness socio-economic perspective (Granovetter, 1985). The social elements that can cause cultural shocks are included in the psychic distance concept, between home country and the direct investment host country (Johanson \& Valhne, 1977). Psychic distance is defined as "the sum of factors preventing the flow of information from and to the market. Examples are differences in language, education, business practices, culture, and, industrial development" (Johanson \& Valhne, 1977, p. 24). Psychic distance reduction increases commitment to the international market, facilitates socio-economic relations between countries and affects the internationalization process of companies (Tanure \& Duarte, 2006), in the same manner that Yoshino (1976) and Ozawa (1979) familiarity theory argues that there is more propensity for direct investments in countries with shortest cultural 
distance. As noted by Berry et al. (2010) cultural distance considered alone significantly dissuades firms from investing in foreign countries. Thus, it is assumed that the greater the similarity between cultures, the greater the ratio of international trade between countries, since uncertainty is reduced and it becomes easier to understand and learn how to negotiate with this country that is culturally closer. National culture is molded according to its fundamental values, which in turn are absorbed and built by people during their childhood, through rules and prohibitions, i.e. during the educational process (Hofstede, 1993). Nations have an educational process standard and develop a collective mental programming, which results in personality models guided by values (Hofstede, 1980, 1991, 1993; Hofstede, Hofstede \& Minkov, 2010).

Hofstede (1980, 1991, 1993) and Hofstede et al. (2010) define six value dimensions: (1) Power Distance; (2) Individualism or Collectivism; (3) Masculinity or Femininity; (4) Uncertainty Avoidance; (5) Long Term Orientation; (6) Indulgence versus Restraint. The original four dimensions (Hofstede, 1980) are utilized because allows a comparative perspective, that is, findings from this work can be analyzed and compared to those derived from studies based on 'conventional cultural distance measurement'. The fifth dimension was developed initially by Michael Harris Bond and was added by Hofstede (1991). Long Term Orientation (Flexumility) means future-oriented and its values are perseverance, thrift, ordering relationships by status and having sense of shame. Short Term Orientation (Monumentalism) means present-oriented and its values are reciprocating social obligations, respect for tradition, protecting one's face and personal steadiness and stability (Hofstede, 2011). The sixth dimension was developed by Minkov (2009) and was added to Hofstede's work in Hofstede et al. (2010). Indulgence means "a society that allows relatively free gratification of basic and natural human desires related to enjoying life and having fun" (Hofstede, 2011, p. 15). Restrain means "a society that controls gratification of needs and regulates it by means of strict social norms" (Hofstede, 2011, p. 15).

The work of Hofstede (1980) has been questioned several times, as by Baskerville (2003) who stated that Hofstede does not study cultural dimensions, but rather reflects socio-organizational mechanisms. Hofstede (2003) defended his work by stating that the anthropological view of culture is more subjective, while in organizational studies the focus is on comparison and objectivity. For Baskerville (2003) countries are not the best units for studying culture, but Hofstede (2003) argued country is the only unit that can be used for comparison. Countries are not the same as cultural nations, but this does not necessarily invalidate the data (Hofstede, 2003).

Shenkar (2012) argues that one of the problems of using Hofstede's data (1980) is that they are not updated and culture can change over time, but authors such as Tanure and Duarte (2006) argue that the Hofstede's indexes do not have significant variations over time. Drogendijk and Slangen (2006) tested and concluded that international business researchers can use Hofstede's cultural distances measures. Hofstede (2003) advises that his measures should not be used in studies between two (or a few) countries, since small replications may not confirm their results, and also because cultural values are more stable to changes than to practices, so his data are not outdated, because changes in the dimensions studied by him would be slow.

Of course, we could use Project GLOBE (Global Leadership and Organizational Behavior Effectiveness) cultural dimensions or Kogut and Singh's index. GLOBE has six dimensions originated from Hofstede and three of them reflect the same construct (Uncertainty Avoidance, Power Distance and Individualism/Collectivism I) (House, Javidan, Hanges \& Dorfman, 2002). Hofstede (2006) argued GLOBE has too many dimensions (nine) and exceeds our capacity for processing information, i.e. those dimensions are too complex to be useful. Kogut and Singh's index is a composite of the four original dimensions of Hofstede, i.e. is an aggregate index (Kogut \& Singh, 1988). Shenkar (2012) says it is better to apply separate rather than aggregate cultural distance index. All models have your own criticisms, but despite criticism Hofstede was one of the first researcher to present a model of cultural values that can be used in quantitative research (Tara, Kirkman \& Stell, 2010).

\section{Hypotheses}

We will present the four hypotheses that will be tested in this paper. The first hypotheses is about the cultural dimension Power Distance. It is a difference of status, power concentration, formal relationships and distancing from superiors (Ferraro, 2002; Hofstede et al., 2010), i.e. it is a measurement of the social hierarchical distance. It also represents the 
relationship of dependency between people (Ferraro, 2002). It refers "to the different solutions to the basic problem of human inequality" (Hofstede, 2011, p. 8), in other words, it indicates to what degree the less powerful believe in social equality. Power distance is "the degree to which members of an organization or society expect and agree that power should be unequally shared" (House et al., 2002, p. 5). When the index is low, it means the employees have more independence and may even contradict their superior, resulting in a more horizontal relationship, while a higher index signifies a more vertical, centralized type of society in the hierarchical sense, with more significant wage differences between the high administration and operational personnel (Hofstede, 1991; Ferraro, 2002; Machado, Santos \& Pinto, 2009). The more hierarchical a society, the greater the distance of power in organizations with power concentrated at the top of the organization (Machado et al., 2009). It is assumed that more centralized societies relating to more decentralized ones would result in cultural shock, especially when FDI is concerned, since this (hierarchy) is a sensitive aspect within the organizational environment and would affect even the structural and organizational model of the company.

$H 1$ : The similarities in cultural values referring to Power Distance between two countries positively affect the FDI stock between them.

Individualism refers to how much each person worries about herself in detriment of group, not caring about loyalty and cohesion between people (Hofstede et al., 2010). In individualist societies the individual interest prevails in detriment to the group, in collectivist ones the opposite is true. Individualism versus Collectivism reflects the integration of individuals into groups (Hofstede, 2011). Collectivism "reflects the degree to which organizational and societal institutional practices encourage and reward collective distribution of resources and collective action" (House at al., 2002, p. 5). Shneider and Arruda (1996, p. 98) define this index as "the degree in which society believes that people must take care of themselves and remain emotionally independent from the groups, organizations and other collective entities". Clashes may occur when the individual brags about their success without sharing their achievements with the group. When both ends of this social values spectrum meet, it may result in awkward situations, negatively affecting the relationships.
$\mathrm{H} 2$ : The similarity in cultural values related to Individualism between countries positively affects the FDI stocks between them.

Masculinity indicates assertiveness, material achievements and competitiveness (Ferraro, 2002). Valade (1995) relates the way people deal with these issues as feminine or masculine character traits, these not being dependent on gender, but on cultural models and on the roles imposed by these models. Masculine traits refer as to how much do values such as money and material goods prevail in a given society, instead of values such as education and quality of life, considered feminine (Shneider \& Arruda, 1996). Masculine versus feminine reflect to the distribution of values between women and men (Hofstede, 2011). Masculinity is related to strength, firmness, competitiveness and outdoor activities while femininity is more related to domestic work, children and docile behavior (Hofstede, 1991). The culture focused on masculinity develops a boss model that emphasizes self-affirmation, aggressiveness and isolated decision. In a culture focused on femininity, the boss is more discreet, acts intuitively, and seeks the consensus of the group (Valade, 1995). Since FDI refers to the companies that are crossing borders, opening offices, creating partnerships and hiring collaborators, searching for common objectives and for the same methods and values, it could generate a synergy between foreigners and locals.

H3: The similarity in cultural values related to the Masculinity between two countries positively influences the FDI stock between them.

The dimension that refers to the degree of Uncertainty Avoidance is one of the more argued in literature in relation to the internationalization of companies. Uncertainty Avoidance is "the extent to which members of an organization or society strive to avoid uncertainty by reliance on social norms, rituals, and bureaucratic practices to alleviate the unpredictability of future events" (House et al., 2002, p. 5). This dimension indicates people's propensity to avoid or take risks (Hofstede, 1980), in other words, it demonstrates people's behavior (uncomfortable or comfortable) when dealing with uncertainty, the unknown (Ferraro, 2002). Uncertainty Avoidance refers "to the level of stress in a society in face of an unknown future" (Hofstede, 2011, p. 8). "The feeling of uncertainty and the ways of facing it are part of society's cultural heritage, being passed on and reinforced by the institutions at the base, such as family, school and State" (Hofstede, 1991, p. 133). 
For companies to invest in foreign markets it is necessary to take risks, which is easier for companies with low Uncertainty Avoidance. Likewise, in choosing the target market for their investments, companies prefer countries with low Uncertainty Avoidance, as this feature strengthens relationships of trust (Bhardwaj et al., 2007). To Shenkar (2012) the differences between countries, relating to Uncertainty Avoidance are the most problematic issue in internationalization processes. People in high Uncertainty Avoidance societies are not good businessmen, since the results from negotiations are never predictable (Ferraro, 2002), i.e. the mistrust between the parties may cause unexpected interruptions to negotiations. Therefore, the presence of High Aversion to Uncertainty in the country of destination or origin may create barriers to FDI. It is assumed that when two countries are similar in this dimension of cultural values, it would be easier for the people of these countries to understand one another.

H4a: The similarity of cultural values concerning Uncertainty Avoidance between two countries affects positively the FDI stock between them.

However, high Uncertainty Avoidance societies are no good negotiators, i.e. theses societies are characterized by anxiety about the future, emotional resistance to change, fear of failure and consequently fear of risk taking (Ferraro, 2002). The presence of this cultural value may become a barrier for international negotiations, both in the home country as in the host country (Bhardwaj et al., 2007). Brouthers and Brouthers (2001) have found in their research that bigger cultural distance along with high aversion to risk between two countries will increase the FDI cost and the relationship cost between them.

$\mathrm{H} 4 \mathrm{~b}$ : The presence of high Uncertainty Avoidance in one or in both countries of a dyad negatively affects the FDI stock between them.

\section{METHODOLOGY}

To test the hypothesis that the similarities in cultural values between two countries influence the FDI stock that those countries have in each other, secondary data from a sample of 45 countries was analyzed. The sample is a result of data availability from the two main variables, from the dependent variable (FDI stock) and the independent one (cultural values). Considering the total population of 234 independent or autonomous States, only 145 had FDI stock data available (ITC, 2012), therefore that was the first limitation faced in relation to the utilized data. The cultural values data was drawn from Hofstede et al. (2010) since their studies are more comprehensive and up-to-date and including 77 countries. Data collection took place in 2012 (Goraieb, 2013) by crossing the FDI stock data (ITC, 2012) and the values measured by Hofstede et al. (2010), a sample of 47 countries was obtained. From these, Romania and Luxemburg were deleted from the sample, for presenting inconsistent data. The remaining 45 countries have available data in both variables (Table 1 ) and therefore remain in the final sample of this research. They represent approximately $95 \%$ of the world's FDI stock and corresponds a $58 \%$ of 77 countries present in Hofstede et al. (2010) study. That is to say that the sample size may be relatively small in terms of number of countries covered, its relevance to IB is substantial. A larger numbers of cultures are important to allow for randomization of variance in cross-cultural research (Sivakumar \& Nakata, 2011).

Countries that took part of the research sample: Australia, Austria, Belgium, Brazil, Bulgaria, Canada, Chile, China, Croatia, Czech Republic, Denmark, Estonia, Finland, France, Germany, Greece, Hong Kong, Hungary, Ireland, Israel, Italy, Japan, Latvia, Lithuania, Malaysia, Morocco, Netherlands, New Zeland, Norway, Pakistan, Poland, Portugal, Singapore, Slovakia, Slovenia, South Africa, South Korea, Spain, Sweden, Switzerland, Thailand, Turkey, United Kingdom, United States and Vietnam (Goraieb, 2013).

\section{Dependent Variable}

The dependent variable is the FDI stock (FDIS) that the home country possesses in the host country, divided by the total FDI from the home country. The FDI stock is the value of the assets accumulated in foreign companies that include part of its shares and reserves in the subsidiary, and the loans made (ITC, 2012). The FDI stock data was obtained from the online Platform, International Trade Centre (ITC, 2012), using the tool Investment Map that is managed and maintained by UNCTAD (United Nations Conference on Trade and Development), COMTRADE (United Nations Commodity Trade Statistics Database) among other organizations. This tool informs how much a home country has invested in the host country, in relation to the total invested around the world by the home country, i.e. it is the percentage of the investment made by a country in 
relation to the total invested. The percentage of FDI stocked in 'tax heavens' in order to regulate proportionally the FDI stock in relation to other countries was discounted. Even though Singapore and Hong Kong are considered 'tax heavens', they were not excluded from the sample, since they are also industrial and commercial powerhouses. Thus, an asymmetric square matrix (directional) was prepared, in which the relationship between the dyad is represented by the percentage that a country has invested in another, in relation to the total invested by the home country in 2007 . The matrix is in a scale of 0 to 100, but the total sum of the relationships of a country is not always 100 , because the sample does not encompass all the countries of total population.

\section{Independent Variables}

The Independent variables are the four dimensions of cultural values presented by Hofstede et al. (2010): (1) Power Distance (IPD); (2) Individualism or collectivism (IIC); (3) Masculinity (IMF); and (4) Uncertainty Avoidance (IAU), applied as separate rather than aggregate cultural distance (Shenkar, 2012). The data concerning the cultural values were gathered from Hofstede et al. (2010) that has charts indicating the rate of each cultural value for each country. The Euclidian distance, geometrically shortest possible distance, between two countries for each cultural value dimension was calculated. Such numerical values were re-scaled from zero to one, by using the SPSS software (PASW statistics 18 version). Subsequently, the dyads values in relation to similarity were changed, calculating the complement of one, i.e. the differences of rate among countries was subtracted from the number one. A matrix was obtained, indicating the similarity between pairs of countries in relation to the dimensions of cultural values measured by Hofstede et al. (2010). A variable called Co-presence of High Uncertainty Avoidance was also created (HAU), since it occurs when two countries have High Uncertainty Avoidance, i.e. when two societies are characterized by anxiety about the future, emotional resistance to change, fear of failure and consequently, to take risks (Ferraro, 2002). To define the presence of HAU between two countries, two groups of Uncertainty Avoidance were created, the first representing low Uncertainty Avoidance and the second representing High Uncertainty Avoidance. Considering as cut-off number, half of the standard deviation from the Uncertainty Avoidance average. The value average is 63.71, considering half of the standard deviation as
11.86. Hence the values above 75.57 are considered High Uncertainty Avoidance, comprising exactly a third of the total sample countries. When two countries exhibit High Uncertainty Avoidance, the dyad is represented by the number 1 , and when only one country High Uncertainty Avoidance, the dyad is represented by the number 0.5 and when no country exhibits High Uncertainty Avoidance, the dyad is represented by the number zero.

\section{Control Variables}

Cultural, economic, geographical and politicaladministrative factors that were considered significant in other researches were included as control variables. Two geographical factors were included as control variables: firstly, geographical proximity (GPR). In this research, one of the measurements developed by Mayer and Zignago (2011) for the models of economic gravity, in which the distance between the countries is considered, by calculating the bilateral distances between the largest cities of the aforementioned countries. This procedure is consistent for international distances, starting from the geographical coordinates and demographic data supplied by the site World Gazetteer. The algorithm developed by Head and Mayer (2009) to calculate the distance between countries ' $i$ ' and ' $j$ ' is

$$
d_{i j}=\left(\sum_{k \in i}\left(\frac{p o p_{k}}{p o p_{i}}\right) \sum_{\ell \in j}\left(\frac{p o p_{l}}{p o p_{j}}\right) d_{k l}^{\theta}\right)^{\frac{1}{\theta}}
$$

where $\operatorname{pop}_{k}$ designates the population of the metropolitan area $k$ belonging to the country i. The parameter $\vartheta$ measures the sensitivity of bilateral trade flows for the distance $d_{k l}$. To calculate the geographical distance, the parameter $v$ must be equal to -1 . These values must be turned into a 0 to 1 scale, dividing the total of the matrix values by the highest value found in this matrix. The proximity was represented by the complement of the results found in this calculation. The second geographical factor to be included was border sharing (BSH). The dyad of adjacent countries received a value of 1 , as suggested by Mayer and Zignago (2011), while the dyad of countries with no shared borders received a value of 0 . Two economic factors were included in the model as control variables: their difference in Gross National Product (GNP) and their difference in Gross National Product Per Capita (GNPPC). Hofstede (2011) recommends when studying cultural dimensions taken in count the influence of national wealth 
(GNPPC). To measure the former, the difference in GNP for the year 2007, in dollars, for each pair of countries, calculated according to data from the International Monetary Fund (IMF). The result is not modular and can be negative, indicating that in the relationship targeting between the two countries, i.e. a dyad $A / B$ in which country $A$ has a GNP higher than country $B$, it is possible to verify that the relationship of $A$ towards $B$ is the reverse of that of $B$ towards $A$, in accordance to the economic gravity theory in which countries with a higher GNP attract more investments than those with lower GNP. The higher the result of this subtraction, higher is the host country's ability of attracting FDI. This ratio was turned into a -1 to 1 scale, dividing all the values by the highest value found. The second economic factor was calculated in the same manner than the previous one, however making use of the GNPPC of each country. The economic factor was also turned into a 1 to 1 scale.

A political-administrative factor was included, legal origin (LEO). The variable indicates if two countries belonged to the same State or the same administrative entity for a long period of time (Mayer \& Zignago, 2011). Long periods are considered 25 to 50 years in the $X X$ century, 25 to 50 years was a long period of time, 75 years or more in the XIX century and 100 years or more in any century before the XIX. The countries dyads that were considered to be from the same legal origin received the value 1 and those that were not received the value 0 (Mayer \& Zignago, 2011). Lastly, same language was used as a cultural control variable as made by Tang (2012). Same Language signifies the presence of the same symbolic communication code, which consists of a series of phonemes with meanings and rules of grammar for the construction of messages in the dyads (Ferraro, 2002). It is considered to be the language of a determinate country when $9 \%$ or more of its population is fluent in this language, but a country can have more than one language (Mayer \& Zignago, 2011). Country pairings with some language in common were considered similar and attributed the value 1 , in those with no common language, the value was 0 . The data was collected from the file "dist_cepii.xls" developed and presented by Mayer and Zignago (2011).

\section{Models}

The dependent variable data, FDI stock, represent the relationships between countries, which resulted in the need to use a specific technique that in turn would deal with the difficulties derived from the utilization of the relational variables and not attributes ones. Since the hypotheses to be tested have as their objective to verify what influence similarities in cultural values have in FDI stock between the countries, this research opted to use a Multiple Regression Quadratic Assignment Procedure (MRQAP). This technique presents itself as appropriate for the dyads' analysis in at least three different situations: (1) when researching the transactions between the agents; (2) when the objective is to analyze the similarity in quantitatively measured behavior; and (3) when the objective is to analyze the similarity in behavior among a series of discrete events (Mizruchi \& Marquis, 2006). When dealing with matrices with dyad data, the Ordinary Least Squares (OLS) technique is not adequate due to lack of observations' independence, since a dyad is made up of a pair of actors and each actor ends up being part of relationships with all the other actors, but itself. The MRQAP is a non-parametric test, based on permutations that preserve the integrity of the observed structures (Krackhardt, 1987). In their studies Dekker, Krackhardt and Snijders (2007) discuss the best way of using the MRQAP and conclude that the technique called Double SemiPartialing (DSP) has shown to be the safest and most robust, and is available on the UCINET's 6.247 version, social media analysis software, and will be used in this research's testing.

The final model to test the hypotheses is:

$F D I S_{i j t}=\beta_{0}+\beta_{1} I P D_{i j}+\beta_{2} I I C_{i j}+\beta_{3} I M F_{i j}+\beta_{4} I A U_{i j}+\beta_{5} H A U_{i j}$ $+\beta_{6} I S L_{i j}+\beta_{7} G P R_{i j}+\beta_{8} B S H_{i j}+\beta_{9} L E O_{i j}+\beta_{10} G N P_{i j t}+\beta_{11} G N P P C_{i j t}$ $+\varepsilon_{\mathrm{ijt}}$

In which time $\mathrm{t}$ is 2007, the year chosen for having FDI stock data available, i represents the home country and $j$ is the host country. The variables are represented in the model by the acronyms FDIS (FDI Stock), IPD (Index Power Distance), IIC (Index Individualism Collectivism), IMF (Index Masculinity Femininity), IAU (Index Uncertainty Avoidance), HAU (High Uncertainty Avoidance), ISL (Index Same Language), GPR (Geographical Proximity), BSH (Border Sharing), LEO (Legal Origin), GNP (Gross National Product) e GNPPC (GNP Per Capita). The $\beta$ 's are regression coefficients.

\section{RESULTS}

On figure 1 the 45 sample countries are introduced, represented as a network in which the 
connections are the FDI stock and their colors represent the geographic region in which they are located, as specified by the caption.

The arrow indicates the direction of the FDI, for example see Greece and Turkey, Greece made FDI in Turkey, but Turkey didn't make FDI in Greece. Arrows in both directions mean both countries made FDI in each other. It is possible to verify that more than half of the countries belong to the European continent, represented by the colors yellow and blue, the latter indicating the East European countries. Brazil is next to this group and is represented by the color red in the same manner that the other countries from the American continents, Middle Eastern and North African countries are also nearer to the European ones (see Turkey and Morocco). At the center of the network are the countries with the more relevant economies worldwide, such as the USA, England, France, Switzerland, Germany, China and Canada. Despite the power of its economy, Japan is not at the center of the network. It is perceived that this country has relationships primarily with the Asian countries group (represented by the color orange), with Oceania and with countries from the American continents which have contact with the Pacific region, especially with the USA.

By observing the network, it is possible to notice that geography plays an important part in the network's configuration separating groups by regions and maritime borders, i.e. the countries geographically closer are also closer within the network.

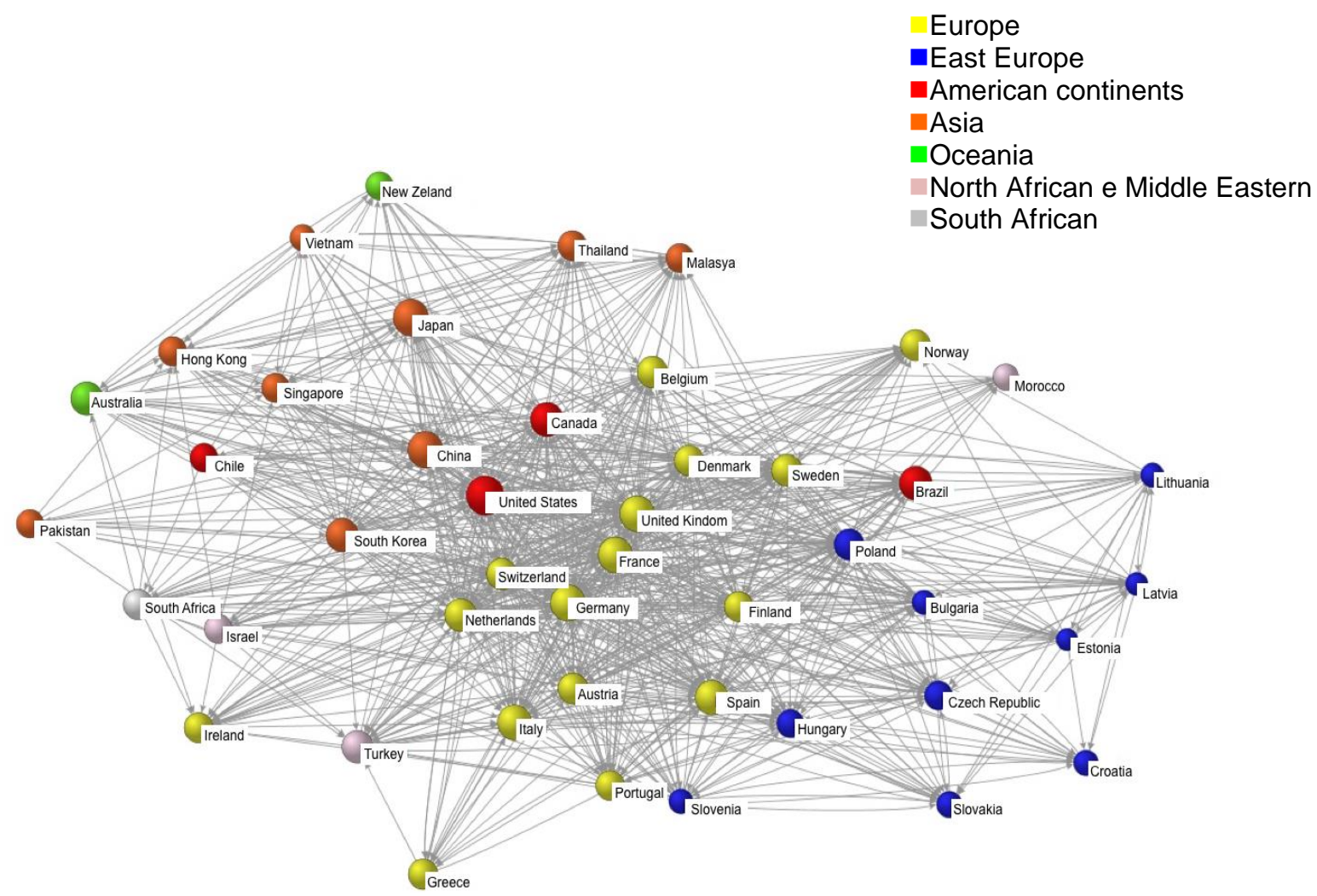

Figure 1 - FDI Stock Network

Source: Research Data

Another prominent factor in FDI relationships seems to be the GNP. The ten countries with the highest GNP in that year are the USA, Japan, China,

Table 1 presents the results of the QAP correlation between the independent and the control variables. Only one case of high correlation was observed: Legal Origin (LEO) and Shared Borders (BSH). However, the
Germany, United Kingdom, France, Italy, Spain, Canada and Brazil. These countries are more central on the network.

Double Semi-Partialing technique (DSP) MRQAP showed strength in cases of multi-collinearity (Dekker et al., 2007). 
Table 1 - QAP correlation between the independent and the control variables

\begin{tabular}{l|l|l|l|l|l|l|l|l|l|l|l|l}
\hline & HAU6 & HAU7 & IPD & IIC & IMF & IAU & ISL & GPR & BSH & LEO & GNP & GNPPC \\
\hline HAU6 & 1,00 & & $0,17^{\star}$ & 0,04 & 0,10 & $-0,08$ & $-0,11$ & 0,07 & $-0,01$ & 0,04 & 0,00 & 0,00 \\
\hline HAU7 & & 1,00 & $0,18^{\star}$ & 0,06 & 0,08 & $0,12^{\star}$ & $-0,08$ & 0,06 & 0,02 & 0,03 & $-0,03$ & $-0,12$ \\
\hline IPD & $0,17^{\star}$ & $0,18^{\star}$ & 1,00 & $0,28^{\star}$ & $0,16^{\star}$ & 0,11 & 0,02 & 0,01 & 0,02 & $-0,09^{\star}$ & 0,00 & 0,00 \\
\hline IIC & 0,04 & 0,06 & $0,28^{\star}$ & 1,00 & $-0,05$ & $0,11^{\star}$ & $-0,03$ & $0,27^{\star}$ & $0,17^{\star}$ & 0,06 & 0,00 & 0,00 \\
\hline IMF & 0,10 & 0,08 & $0,16^{\star}$ & $-0,05$ & 1,00 & $-0,04$ & $0,25^{\star}$ & $-0,15^{\star}$ & 0,05 & $-0,09^{\star}$ & 0,00 & 0,00 \\
\hline IAU & $-0,07$ & $0,12^{\star}$ & 0,11 & $0,11^{\star}$ & $-0,05$ & 1,00 & 0,07 & 0,08 & $0,13^{\star}$ & 0,06 & 0,00 & 0,00 \\
\hline ISL & $-0,11$ & $-0,08$ & 0,02 & $-0,03$ & $0,25^{\star}$ & 0,07 & 1,00 & $-0,07$ & $0,15^{\star}$ & 0,04 & 0,00 & 0,00 \\
\hline GPR & 0,07 & 0,06 & 0,01 & $0,27^{\star}$ & $-0,15^{\star}$ & 0,08 & $-0,07$ & 1,00 & $0,25^{\star}$ & $0,16^{\star}$ & 0,00 & 0,00 \\
\hline BSH & $-0,01$ & 0,02 & 0,02 & $0,17^{\star}$ & 0,05 & $0,13^{\star}$ & $0,15^{\star}$ & $0,25^{\star}$ & 1,00 & $0,42^{\star}$ & 0,00 & 0,00 \\
\hline LEO & 0,04 & 0,03 & $-0,09^{\star}$ & 0,06 & $-0,09^{\star}$ & 0,06 & 0,04 & $0,16^{\star}$ & $0,42^{\star}$ & 1,00 & $-0,00$ & $-0,00$ \\
\hline GNP & 0,00 & $-0,03$ & 0,00 & 0,00 & 0,00 & 0,00 & 0,00 & 0,00 & 0,00 & $-0,00$ & 1,00 & 0,21 \\
\hline GNPPC & 0,00 & $-0,12$ & 0,00 & 0,00 & $0,00^{\star}$ & 0,00 & 0,00 & 0,00 & 0,00 & $-0,00$ & 0,21 & 1,00 \\
\hline
\end{tabular}

$\star p<0,01$

- $\mathrm{p}<0,05$ Source: Research data

The results of the regression are presented on table 2. The tests were initiated by the control variables on model 1 . The model's adjusted $R^{2}$ was 0.213 and statistically significant (0.000 probability). Geographic Proximity (GPR), Border Sharing (BSH), the difference in GNP, the same Legal Origin (LEO) and the coexistence of the same language (ISL) are statistically significant to $99 \%(p<0.01)$ and the relationship's direction is in accordance to what was previously established in the literature. Only the difference GNPPC was not significant.

Table 2 - MRQAP results

\begin{tabular}{l|c|c|c|c|c|c|c}
\hline \multirow{2}{*}{} & \multicolumn{2}{|c}{ Models } \\
\cline { 2 - 7 } & 1 & 2 & 3 & 4 & 5 & 6 & 7 \\
\hline IPD & & & & $0,082^{\star}$ & $0,098^{\star}$ & $0,099^{\star}$ \\
\hline IMF & & & & $0,047^{\star}$ & 0,023 & 0,022 & 0,022 \\
\hline IAU & & 0,024 & 0,026 & 0,022 & 0,014 & 0,007 & 0,026 \\
\hline HAU7 & & & & & & & $-0,102^{\star}$ \\
\hline HAU6 & & & & & & $-0,091^{\star}$ & \\
\hline ISL & $0,177^{\star}$ & $0,176^{\star}$ & $0,169^{\star}$ & $0,171^{\star}$ & $0,173^{\star}$ & $0,161^{\star}$ & $0,162^{\star}$ \\
\hline LEO & $0,144^{\star}$ & $0,143^{\star}$ & $0,147^{\star}$ & $0,149^{\star}$ & $0,156^{\star}$ & $0,164^{\star}$ & $0,161^{\star}$ \\
\hline GNP PC & 0,038 & 0,038 & 0,038 & 0,038 & 0,038 & 0,038 & 0,027 \\
\hline GNP & $0,169^{\star}$ & $0,169^{\star}$ & $0,169^{\star}$ & $0,169^{\star}$ & $0,169^{\star}$ & $0,169^{\star}$ & $0,169^{\star}$ \\
\hline
\end{tabular}




\begin{tabular}{|c|c|c|c|c|c|c|c|}
\hline $\mathrm{BSH}$ & $0,248^{\star}$ & $0,246^{\star}$ & $0,243^{\star}$ & $0,236^{\star}$ & $0,236^{\star}$ & $0,233^{\star}$ & $0,235^{\star}$ \\
\hline GPR & $0,092^{\star}$ & $0,091^{\star}$ & $0,095^{\star}$ & $0,084^{\star}$ & $0,087^{\star}$ & $0,095^{\star}$ & $0,093^{\star}$ \\
\hline Intercept & $-0,431$ & $-0,926$ & $-1,649$ & $-2,108$ & $-3,086$ & $-3,045$ & $-3,581$ \\
\hline $\mathrm{R}^{2}$ & 0,215 & 0,215 & 0,216 & 0,218 & 0,224 & 0,232 & 0,234 \\
\hline $\mathrm{R}^{2}$ adjusted & 0,213 & 0,213 & 0,213 & 0,215 & 0,220 & 0,228 & 0,230 \\
\hline Probability & 0,000 & 0,000 & 0,000 & 0,000 & 0,000 & 0,000 & 0,000 \\
\hline
\end{tabular}

In model 2 has been inserted IAU independent variable, which refers to the cultural value Uncertainty Avoidance. This variable is not significant, as well as the similarity of cultural value Masculinity and Femininity (IMF) tested in the model 3. None of these two variables influence the FDI, which does not support the hypothesis $\mathrm{H} 4 \mathrm{a}$ and $\mathrm{H} 3$, that is, the similarity or difference between countries in cultural values Uncertainty Avoidance and Masculinity not affect FDI.

In model 4, significance was found regarding the similarity cultural Individualism and Collectivism, suggesting that the similarity in the cultural value Individualism positively influences FDI between countries, however, when it included the similarity of Power Distance (model 5) the similarity of cultural value Individualism loses significance, not supporting the hypothesis $\mathrm{H} 2$. In model 5 the cultural values similarities variables were added. The adjusted $R^{2}$ rises to 0.220 , which is still statistically significant, indicating an improvement on the model's explanatory power. The control variables continue to be significant and only the similarity in power distance variable (IPD) presented significance to $99 \%$ and in the expected direction, supporting $\mathrm{H}$ 1. In models 6 and 7, hypothesis H4b was tested, with the inclusion of the co-existence of the High Uncertainty Avoidance variable (HAU). The difference between these two models is found in the way that the coexistence is represented in the relational matrix. In model 6 the co-existence of the High Uncertainty Avoidance variable (HAU6), when both countries presented a high aversion the value is 1 , when only one of this countries had a high aversion the value is 0.5 and when neither country had high aversion the value is 0 . In model 7 the co-existence of the High Uncertainty Avoidance variable (HAU7) receives the value 0.5 only when the host country has high aversion. In both models the variable appears as statistically significant and in the direction expected by the literature, supporting $\mathrm{H} 4 \mathrm{~b}$. In model 6 , however, the significance is to $95 \%$, while in model 7 it is $99 \%$. The adjusted $R^{2}$ in model 5 presents a higher improvement than the one in model 5 , indicating that this model explains in better terms the relationship this variable has with the FDI stock.

To sum up, when the influence of the similarities in cultural values in FDI is tested, only the power distance is significant and positively related, supporting $\mathrm{H} 1$. The similarities among the cultural values of Masculinity, Individuality and Uncertainty Avoidance are not statistically significant; therefore, $\mathrm{H} 2, \mathrm{H} 3$ and $\mathrm{H} 4$ were not supported. Also that the Coexistence of High Uncertainty Avoidance is negatively related to FDI was supported, which in turn, supported H4b.

Lastly, the results demonstrate that (1) the technique utilized brings the same results to the control variable as other previously used techniques, reinforcing the correctness of the choice of this technique, (2) hypotheses $\mathrm{H} 1$ and $\mathrm{H} 4 \mathrm{~b}$ were supported, (3) cultural values do influence FDI, complementing the explanation of FDI stocks around the world and (4) it is necessary to pay more attention the similarity of cultural value Distance of Power and the presence (and the co-presence) of Uncertainty Avoidance in FDI studies. Summarizing, it was found that the similarities in Power Distance between two countries positively affects the FDI stock between them and the presence of high Uncertainty Avoidance in one or in both countries of a dyad negatively affects the FDI stock between them. Common language between two countries has a positive influence on bilateral FDI, that is, a company first invest in a country that speaks the same language (Tang 2012). From the practical point of 
view, when making FDI decisions (1) the presence of high Uncertainty Avoidance in one or in both countries of a dyad, it means that companies avoid countries that are different from their home country and (2) the similarities in Power Distance between two countries; it means that companies prefer countries similar from their home country.

\section{DISCUSSION}

The results indicate that cultural values influence the FDI between countries; nevertheless this influence does not happen in equal manner to all the different dimensions identified by Hofstede et al. (2010), which is consistent with the separation of cultural values in four dimensions. Furthermore, these authors discuss in depth intra-organizational issues related to those dimensions and the concepts developed by the authors have that characteristic since they were first measured within the same organization. The analysis does not consider companies that invest abroad separately, but their FDI, that may influence the results. Even so, two of the dimensions influenced the FDI. The Power Distance index (PDI) showed a positive relationship with the FDI, therefore countries with similar power distance indexes tend to have more FDI stock in each other than those that do not have similarity. A part of this relationship may be explained by the relation between Society and State. In countries with a low power distance index, the relationships are more equal and less authoritarian. On the other hand, countries with a high power distance index, the relationship is more authoritarian and there are less equalities. The relationships between the organizations with the State are important when deciding to make FDI. Organizations that are used to relating to the State in a certain way, may feel more comfortable dealing with governments that act in similar fashion to theirs, leading to a higher level of investment in countries with similar power distance indexes. In the Uncertainty Avoidance case, it is not the similarity of cultural value in this dimension that is the influence, but the presence of High Uncertainty Avoidance (HAU) in both countries or in the home country. The relationship is negative, i.e. the existence of $\mathrm{HAU}$ in both countries or in the home country diminishes one country's presence of FDI in the other one. This occurs because making FDI involves risk and the higher Uncertainty Avoidance; the higher is the aversion to risk. Moreover, according to Hofstede et al. (2010), countries with a high Uncertainty Avoidance tend to create more rules and barriers to regulate foreign capital entry, since they feel more comfortable with a stricter system of rules.

These results support the understanding of cultural friction, that is, if cultural differences effectively undermine economic relations (Shenkar, 2012) by the socioeconomic perspective of social embeddedness (Granovetter, 1985), using methods not usual in this area of studies such, as Social Network Analysis and Multiple Regression Quadratic Assignment Procedure (Reinert \& Maciel, 2011), which bring new possibilities for understanding and studying the problem, although it also presents its limitations, such as the absence of attribute data.

As limitations of the research we have the sample size and the level of explanation (R2 adjusted) not very high. In relation to the level of explanation not very high, this leads us to suggest comparisons with the models and techniques already developed to study the same research problem. One of the reasons for this level of explanation may be the absence of some economic factors and other factors that are attributes of the countries, such as the ease of opening new companies. Therefore, this limitation may have occurred because the model does not include all possible factors and variables, using only relational data, but it brings new possibilities and ways of explaining the phenomenon.

It is suggested as future research to deepen this methodology by means of comparison or complementation, using the economic model of gravity, as well as the inclusion of more variables in the model and the more detailed study of the moments in which the culture effectively interferes in the FDI. It is also suggested to replicate this research with more current data and with a larger sample of countries.

\section{CONCLUSIONS}

In this work, a number of factors that may influence FDI were enumerated, a model that included cultural factors was elaborated and such a model was statistically tested. The objectives were achieved using techniques that were not usual, but which were adequate, mainly due to the socioeconomic aspect and the social embeddedness perspective of the research. Although some hypotheses have not been corroborated, the influence of cultural issues in the FDI and, therefore, in the internationalization of companies has been 
proven. Uncorroborated hypotheses help to explain Shenkar's (2012) questioning that not always differences between cultures will result in a negative influence on their relationships, and hence on cultural shocks. This question was clarified statistically, since it used data that considered the contact already occurred between the cultures, helping the understanding of this relevant question for the study area.

Similar countries in hierarchies and Distance of Power among people, social and cultural issues, have been significant in the relations of internationalization between countries, especially in FDI. Therefore more horizontal societies (where people can contradict their superiors) prefer to invest and maintain this investment in similar societies in this matter. The opposite is also true, that is, vertical societies with well defined hierarchical positions, with centralized and socially unequal decisions, prefer to invest and internationalize in societies such as their own. This issue is sensitive in organizations (Hofstede et al., 2010), and therefore should influence the internationalization of companies. Probably people from highly hierarchical societies do not tolerate insubordination of lower level, whereas people from more egalitarian societies may view hierarchical societies as retrograde and unfavorable to innovation and creativity.

Uncertainty Avoidance is also a cultural factor that has proven to interfere in the relations of internationalization and FDI, but in a different way from the Distance of Power, it is the presence of High Uncertainty Avoidance that has effect in FDI. That is, when Uncertainty Avoidance is high in the country of origin and destination, or only in the destination country, the lower the probability of FDI between two countries. This result is intriguing, because it is believed that the High Uncertainty Avoidance in the country of origin should be more significant, since it is this country that invests and which therefore faces greater risks. However, the statistical results of this research showed the opposite, being more significant the presence of High Uncertainty Avoidance in the destination country as a negative factor for FDI. Bhardwaj et al., (2007) argue that the importance of low Uncertainty Avoidance in the destination country is conducive to FDI because it strengthens trust between people and facilitates business.

These two social aspects (Distance of Power and Uncertainty Avoidance) are not yet fully explored fields, and studies in these directions can complement explanations about the internationalization of firms and FDI. It is suggested to deepen in the moments in which the similarity of the cultural value Distance of the Power effectively has effect in the FDI. This applies even to the dimensions of cultural values that have not been shown to be significant in these tests, but which can be treated in different ways, such as the question of individualism in which the doubt arises: individualist culture countries would attract more FDI than countries collectivists? Perhaps another way of testing the influence of Individualism is not through resemblance, but rather through the co-presence of a high level of Individualism or the presence of a high level of Individualism in the destination country. Therefore, other ways of dealing with differentiated data and methods may be interesting to verify such relationships between culture and FDI, and may provide further clarification.

The paper makes several contributions to extant literature. First, the paper uses an innovative approach 'MRQAP technique' to analyze how individual cultural dimensions influence FDI. Second, the paper responds to the critique by Shenkar (2012), by applying separate rather than aggregate cultural distance in empirical research. Third, this paper uses a sample size of 45 countries that represents approximately $95 \%$ of the world's FDI stock and corresponds a $58 \%$ of 77 countries present in Hofstede et al. (2010) study. That is to say that the sample size may be relatively small in terms of number of countries covered, its relevance to IB is substantial. A larger numbers of cultures are important to allow for randomization of variance in cross-cultural research (Sivakumar \& Nakata, 2011). Fourth, this research uses the MRQAP technique to analyze the influential factors of FDI, thus enabling it to test the cultural distances influence on economic results hypotheses and verifying the importance of cultural values in decisions about FDI. The MRQAP presented similar results to other techniques used to test the other factors to influence FDI, with the advantage of including similarity of cultural values. Fifth, cultural values affect FDI between countries, even when controlling economic, geographic and political-administrative aspects, and including other more objective cultural factors such as language. The more subjective values and therefore more difficult to identify should be considered in FDI research. Sixth, certain cultural values may have more influence 
than others on FDI. At the same time as it ratifies the difference in the dimensions proposed by Hofstede, it suggests that the influence of those cultural values depend on specific characteristics of each of these values and not only on the psychic distance or cultural differences. The results from Uncertainty Avoidance support this affirmation, since it is its existence in both countries or in just the host country, which

\section{REFERENCES}

Andersson, S. (2004). Internationalization in different industrial contexts. Journal of Business Venturing, 19, 851-875.

Baskerville, R.F. (2003). Hofstede never studied culture. Accounting, Organizations and Society, 28(1), 1-14.

Berry, H., Guillén, M.F. \& Zhou, N. (2010). An institutional approach to cross-national distance. Journal of International Business Studies, 41, 1-21.

Beugelsdijk, S., Kostova, T. \& Roth, K. (2017). An overview of Hofstede-inspired country-level culture research in international business since 2006. Journal of International Business Studies, 48(1), 30-47.

Bhardwaj, A., Dietz, J., \& Beamish, P. W. (2007). Host country cultural influences on foreign direct investment. Management International Review, 47, 29-50.

Brouthers, K., \& Brouthers, L. (2001). Explaining the national culture distance paradox. Journal of International Business Studies, 32, 177-189.

Dekker, D., Krackhardt, D., \& Snijders, T. (2007). Sensitivity of MRQAP test to collinearity and autocorrelation conditions. Psychometrika, 72 (4), 563-581.

Delios, A., \& Henisz, W.J. (2003a). Policy uncertainty and the sequence of entry by Japanese firms, 1980-1998. Journal of International Business Studies, 34, 227-241.

Delios, A., \& Henisz, W.J. (2003b). Political hazards, experience, and sequential entry strategies: the international expansion of Japanese firms, 19801998. Strategic Management Journal, 24, 11531164.

Dow, D., \& Ferencikova, S. (2010). More than just cultural distance: testing new distance scales on FDI in Slovakia. International Business Review, 19, 46-48. negatively affects FDI. This is coherent with the established hypothesis and the description of the construct proposed by Hofstede, which is, countries averse to uncertainty tend to create more rules and regulations, which in turn create obstacles to the FDI. The fact that the variable in both countries, or only in the host country, offers better explanation than the other tested alternatives strengthens this conclusion.

Drogendijk, R. \& Slangen, A. (2006). Hofstede, Schwartz, or managerial perceptions? The effects of different cultural distance measures on establishment mode choices by multinational enterprises. International Business Review, 15 (4), 361-380.

Du, J., Lu, Y. \& Tao, Z. (2012).Institutions and FDI location choice: the role of cultural distances. Journal of Asian Economics, 23 (2), 210-223.

Feenstra, R.C., Markusen, J.R., \& Rose, A. K. (2001). Using the gravity equation to differentiate among alternative theories of trade. Canadian Journal of Economics, 34 (2), 430-447.

Feils, D.J., \& Rahman, M. (2011). The impact of regional integration on insider and outsider FDI. Management International Review, 51, 41-63.

Ferraro, G. P. (2002). The cultural dimension of international business. New Jersey: Prentice Hall.

Gao, T. (2005). Foreign direct investment in China: how big are the roles of culture and geography? Pacific Economic Review, 10 (2), 153-166.

Ghemawat, P. (2001). Distance still matters: the hard reality of global expansion. Harvard Business Review, 79 (8), 137-147.

Goraieb, M. R. (2013). A relação entre valores culturais e Investimento Direto Estrangeiro (IDE). (Dissertação de Mestrado). Programa de PósGraduação em Administração, Universidade Estadual de Maringá, Maringá, Brasil.

Goulart, L., Brasil, H. V., \& Arruda, C. A. (1996). A internacionalização de empresas brasileiras: motivações e alternativas. In: Fundação Dom Cabral. Internacionalização de empresas brasileiras. Rio de Janeiro: Qualitymark.

Granovetter, M. (1985). Economic action and social structure: the problem of embeddedness. American Journal of Sociology, 91 (3), 481-510. 
Head, K. \& Mayer, T. (2009). Illusory border effects: distance mismeasurement inflates estimates of home bias in trade. In: Bergeijk \& Brakman. The Gravity Model in international trade: advances and applications. Cambridge: Cambridge University Press.

Hejazi, W., \& Ma, J. (2011). Gravity, the English language and international business. Multinational Business Review, 19 (2), 152-167.

Hofstede, G. (1980). Culture's consequences: international differences in work-related values. Beverly Hills, London: Sage Publications.

Hofstede, G. (1991). Culturas e Organizações: como compreender a nossa programação mental. 1. ed. Edições Síbalo: Lisboa.

Hofstede, G. (1993). Cultural constrains in management theories. Academy of Management Executive, 7 (1), 81-94.

Hofstede, G. (2003). What is culture? A reply to Baskerville. Accounting, Organizations and Society, 28, 811-813.

Hofstede, G. (2006). What did GLOBE really measure? Researchers' minds versus respondents' minds. Journal of International Business Studies, 37 (6), 882-896.

Hofstede, G. (2011). Dimensionalizing Cultures: The Hofstede Model in Context. Online Readings in Psychology and Culture, 2(1), 1-26. https://doi.org/10.9707/2307-0919.1014

Hofstede, G., Hofstede, J., \& Minkov, M. (2010). Cultures and Organizations: software of the mind. 3. ed. London: McGraw-Hill.

House, R., Javidan, M., Hanges, P. \& Dorfman. (2002). Understanding cultures and implicit leadership theories across the globe: and introduction to project GLOBE. Journal of World Business, 37, 3-10.

International Trade Centre. ITC. (2012). Investment Map. http://legacy.intracen.org/marketanalysis/DistanceL earning.aspx. Acessed 10.05.12.

Johanson, J., \& Vahlne, J. (1977). The internationalization process of the firm. Journal of International Business Studies, 8, 23-32.

Johanson, J., \& Vahlne, J. (1990). The mechanism of internationalization. International Marketing Review, 7(4), 11-24.
Johanson, J., \& Vahlne, J. (2003). Business relationship learning and commitment in the internationalization process. Journal of International Entrepreneurship, 1 (1), 83-101.

Johanson, J., \& Vahlne, J. (2006). Commitment and opportunity development in the internationalization process: a note on the Uppsala internationalization process model. Management International Review, 46(2), 165-178.

Johanson, J., \& Vahlne, J. (2009). The Uppsala internationalization process model revisited: from liability of foreignness to liability of outsidership. Journal of International Business Studies, 40, 14111431.

Kirkman, B.L., Lowe, K.B., \& Gibson, C. (2006). A quarter century of "Culture's Consequences": a review of empirical research incorporating Hofstede's cultural framework. Journal of International Business Studies, 37(3), 285-320.

Kirkman, B.L., Lowe, K.B., \& Gibson, C. (2017). A retrospective on "Culture's Consequences": the 35year journey. Journal of International Business Studies, 48(1), 12-29.

Krackhardt, D. (1987). QAP Partialing as a Test of Spuriousness. Social Networks, 9, 171-186.

Kogut, B. \& Singh, H. (1988). The Effect of National Culture on the Choice of Entry Mode. Journal of International Business Studies, 19(3), 411-432.

Leung, K.R.S., Bhagat, N.R.B., Erez, M., \& Gibson, C. B. (2005). Culture and international business: recent advances and their implications for future research. Journal of International Business Studies, 36, 357-378.

López-Duarte, C., Vidal-Suárez, M.M., \& GonzálezDiaz, B. (2015). Impact of cultural positions on FDI's entry mode. Cross Cultural Management, 22(3), 509526.

Machado, D. D. P. N., Santos, A. F. \& Pinto, V. M. (2009). Dimensões da cultura organizacional no modelo de Hofstede: aplicações em uma organização militar do exército brasileiro e um órgão público do poder judiciário. In: Seminários em Administração da FEA-USP (SemeAd), São Paulo. Anais do XII SEMEAD: Empreendedorismo e inovação. São Paulo: USP, 1, 1-16.

Makino, S., \& Tsang, E.W. (2011). Historical ties and foreign direct investment: an exploratory study. 
Journal of International Business Studies, 32, 545557.

Malhotra, S., Sivakumar, K., \& Zhu, P. (2009). International Marketing Review, 26 (6), 651-673.

Mayer, T., \& Zignago, S. (2011). Notes on CEPII's distances measures: the GeoDist database. http://www.cepii.fr/anglaisgraph/workpap/pdf/2011 Lwp2011-25.pdf Acessed 20.08.12

Minkov, M. (2009). Predictors of differences in subjective well-being across 97 nations. Crosscultural Research, 43(2), 152-179.

Mizruchi, M.S., \& Marquis, C. (2006). Egocentric, sociocentric, or dyadic: Identifying the appropriate level of analysis in the study of organizational networks. Social Networks, 28 (1), 187-208.

Ozawa, T. (1979). International investment and industrial structure: new theoretical implications from the Japanese experience. Oxford Economic Papers, 31 (1), 72-92.

Polanyi, K. (1944). The Great Transformation. Boston: Beacon Press Boston.

Reinert, M. \& Maciel, C.O. (2011). A influência das relações para a compreensão da semelhança na ação dos indivíduos: uma análise a partir das díades. Anais do XI Congresso Luso Afro Brasileiro de Ciências Sociais. Salvador: UFBA.

Rothaermel, F.T., Kotha, S., \& Steensma, H.K. (2006). International market entry by U.S. Internet firms: an empirical analysis of country risk, national culture, and market size. Journal of Management, 32(1), 56-82.

Schweizer, R., Vahlne, J., \& Johanson, J. (2010). Internationalization as an entrepreneurial process. Journal of International Entrepreneurship, 8 (4), 343370.

Shenkar, O. (2001). Cultural distance revisited: Towards a more rigorous conceptualization and measurement of cultural differences. Journal of International Business Studies, 32, 519-535.

Shenkar, O. (2012). Cultural distance revisited: Towards a more rigorous conceptualization and measurement of cultural differences. Journal of International Business Studies, 43, 1-11.

Shneider, S.C., \& Arruda, C.A. (1996). Gerenciando através de culturas. In: Fundação Dom Cabral. Internacionalização de empresas brasileiras. Rio de Janeiro: Qualitymark.

Sivakumar, K.; Nakata. C. (2001). The stampede toward hofstede's framework; avoiding the sample design pit in cross-cultural research. Journal of International Business Studies, 32 (3), 555-574.

Tang, L. (2012). The direction of cultural distance on FDI: attractiveness or incongruity? Cross Cultural Management, 19(2), 233-256.

Tanure, B., \& Duarte, R. G. (2006). O impacto da Diversidade Cultural na Gestão Internacional. In: Tanure, B., \& Duarte, R. G. (Orgs.) Gestão Internacional. São Paulo: Saraiva.

Tara, V., Kirkman, B. L., \& Steel, P. (2010). Examining the impact of culture's consequences: $A$ three-decade, multilevel, meta-analytic review of Hofstede's cultural value dimensions. Journal of Applied Psychology, 95(3), 405-439.

Thomas, D.E., \& Grosse, R. (2001). Country-oforigin determinants of foreign direct investment in an emerging market: the case of Mexico. Journal do International Management, 7, 59-79.

Valade, B. (1995). Cultura. In: Boudon, R. Tratado de Sociologia. Rio de Janeiro: Zahar.

Yoshino, M. Y. (1976). Japan's multinational enterprises. Cambridge, MS: Harvard University Press. 


\title{
SOBRE OS AUTORES
}

- Marcelo Ribeiro Goraieb - Universidade Estadual de Maringá - UEM, Maringá, Paraná, (Brasil). E-mail: marcelo.rg@gmail.com Orcid id: https://orcid.org/0000-0002-8225-050X

- Maurício Reinert do Nascimento - Universidade Estadual de Maringá - UEM, Maringá, Paraná, (Brasil). E-mail: m.reinert@gmail.com Orcid id: https://orcid.org/0000-0003-0263-9484

- Fabiane Cortez Verdu - Universidade Estadual de Maringá - UEM, Maringá, Paraná, (Brasil). E-mail: fcverdu@uem.br Orcid id: https://orcid.org/0000-0002-1723-5573

\section{INFLUÊNCIAS CULTURAIS NO INVESTIMENTO DIRETO NO EXTERIOR}

\author{
Marcelo Ribeiro Goraieb, Maurício Reinert do Nascimento \& Fabiane Cortez Verdu
}

Universidade Estadual de Maringá - UEM, Paraná, (Brasil)

ARTICLE DETAILS
Histórico do Artigo:
Recebido em: 03 de maio de 2018
Aceito: 08 de novembro de 2018
Disponível online: 01 de abril de 2019
Sistema de revisão “Double blind revieW
Scientific Editor
Ilan Avrichir
Palavras-chave
Influências Culturais
Investimento Direto no Exterior (IDE)
Culturas Nacionais
Distância Cultural
Hofstede

\begin{abstract}
O atual ambiente competitivo de negócios tem influenciado empresas a cruzar fronteiras para explorar mercados externos. A decisão sobre em que país a empresa deveria investir não é fácil. Muitos fatores pode influenciar esta decisão, e cultura é um destes fatores que pesquisadores de negócios internacionais têm incorporado em seus trabalhos. Este artigo lida com a influência de distâncias culturais no Investimento Direto no Exterior, especificamente tem como objetivo examinar se valores culturais afetam o Investimento Direto no Exterior Bilateral, ou seja, o Estoque de Investimento Direto no Exterior. Dados que incluem técnica de Procedimento de Atribuição Quadrática de Regressão Múltipla bilateral entre 45 países em 2007 foram utilizadas, representando quase 95\% do Estoque de Investimento Direto no Exterior no mundo. A Técnica de Procedimento de Atribuição Quadrática de Regressão Múltipla foi utilizada. Foi encontrado que similaridades em Distância de Poder entre dois países afeta positivamente o estoque de Investimento Direto no Exterior entre eles (isto significa que empresas preferem países similares de seu país doméstico) e a alta presença de Aversão à Incerteza em um ou ambos países de uma díade afeta negativamente o estoque de Investimento Direto no Exterior entre eles (isto significa que empresas evitam países que são diferentes de seu país doméstico). Contribuições: (1) usa uma abordagem inovadora a técnica de Procedimento de Atribuição Quadrática de Regressão Múltipla para analisar como dimensões culturais individuais influenciam o Investimento Direto no Exterior; (2) responde à critica de Shenkar ao aplicar índices separados em vez de índice de distância cultural agregada; (3) revela como algumas dimensões culturais influenciam o Investimento Direto no Exterior.
\end{abstract}

(C) 2018 Internext | ESPM. All rights reserved!

\section{Para citar este artigo:}

